\title{
Signalling legitimacy for SMEs transition environments - the case of the Bulgarian IT Sector*
}

\author{
Olga Ivanova, Sylvaine Castellano ${ }^{* *}$
}

This research looks at legitimacy challenges of SMEs evolving in transition environments. Facing lower visibility, higher institutional pressures and limited resources, SMEs experience stronger need to demonstrate their legitimacy, their adherence to the requirements of evaluating audiences. Two types of legitimacy are discussed - functional and relational - that better capture the legitimacy needs of SMEs in transitional contexts. Being multi-dimensional constructs, their dimensions are identified, and measurements are proposed and tested using the structural equation modelling technique. The model was tested on data from the Bulgarian IT sector.

Diese Untersuchung befasst sich mit den Herausforderungen der Legitimation von KMU in sich stark verändernden Umwelten. Angesichts geringerer Sichtbarkeit, höherer institutioneller Zwänge und begrenzter Ressourcen haben KMU eine stärkere Notwendigkeit, ihre Legitimität, ihre Befolgung von Anforderungen eines kritischen Publikums zu demonstrieren. Zwei Arten von Legitimität werden diskutiert - die funktionale und die relationale - das dem besseren Erfassen der Legitimitätsbedürfnisse von KMU in Übergangssituationen dient. Ihre Dimensionen werden identifiziert sowie Messungen vorgeschlagen und getestet, mit Hilfe der Strukturgleichungsmodell-Technik. Das Modell wurde basierend auf Daten aus der bulgarischen IT-Branche getestet.

Key words: signalling theory, organisational legitimacy, transition environments, SMES

\footnotetext{
Manuscript received: 28.01.2012, accepted: 28.09.2012 (1 revision)

** Olga Ivanova, Assistant professor in Marketing, ICN Business School, France. Main research interests: Strategic marketing and management, institutional theory, process of transition and management and marketing challenges for SMEs and entrepreneurial ventures operating in transitional contexts. Corresponding address: olga.ivanova@icngroupe.fr

Sylvaine Castellano, Associate professor, Head of the Management \& Strategy Department at ESG Management School, France. Main research interests: Strategic management, Institutional theories, particular issues of investigation include competitive dynamics, social evaluation of firms through the concepts of legitimacy, reputation and status. Corresponding address: scastellano@esg.fr
} 


\section{Introduction}

The process of institutional transition from one coordination mechanism to another one is an important period in the evolution of any society. An environment going through transition is characterized by high level of vulnerability and uncertainty which impacts all actors, including the organisations (Peng 2003). The dynamic relationship existing between the environment and the organisation is reflected in the concept of legitimacy.

The success of the transition directly depends on the strategies of organisations operating in such environments (Peng 2000a). Small and medium-size enterprises (SMEs) ${ }^{1}$ play an important role as catalysts of the change process (McIntyre 2003:1) since they are expected to spur economic growth and employment (Peng 2000a), and maintain social peace (McIntyre 2003:1). Despite their central role in transition environments, little is known about the challenges that SMEs face and the actions that can be undertaken in order to overcome them (Danis et al. 2010).

One of the main challenges of SMEs in transition environments is to demonstrate that they are legitimate players which implies that they comply with the expectations of relevant stakeholders' groups. The main objective of this study is to shed light on how SMEs in transition environments gain legitimacy which is necessary for obtaining stakeholders' support. The paper is structured in two main parts - theoretical and empirical. First, we examine the specificities of the transition environments. Second, we identify the legitimacy challenges organisations (including SMEs) in transition contexts face. Third, we look at the concept of organisational legitimacy in general and the functional and relational legitimacy in particular. Fourth, we look at the empirical setting, the methodology used and the results of the statistical analysis.

\section{Theory}

\section{Transition environments}

Transition environments are contexts that go through the process of transition. Transition represents a specific period of time characterized by a change from one identified stage to another. This process relates to the concept of institutional change but it does not completely overlap with it - the transition indeed is an integral part of the process of institutional change.

Indeed, institutional change is the process that "witnesses the deinstitutionalization of existing forms and their replacement by new arrangements, which, in time, undergo institutionalization" (Scott 2001). The process of institutional change is comprised of the following stages (see Figure

\footnotetext{
The terms small- and medium-size enterprises (SMEs) and small organizations/firms are used interchangeably in this research.
} 
1): (1) institution formation (institutionalization) - the process when institutions are formed (Scott 2001); (2) deinstitutionalization - the process by which "institutions weaken and disappear" (Scott 2001), and (3) reinstitutionalization the adoption of new practices (Rao et al. 2003).

\section{Figure 1: The process of institutional change}

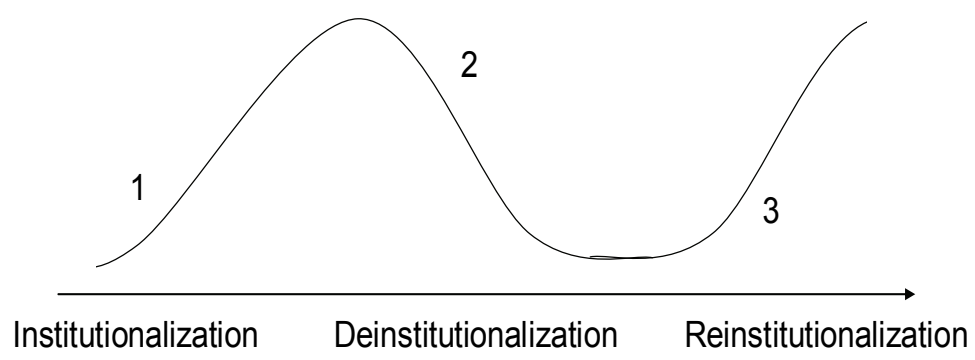

Institutional transition represents a part of the process of institutional change. It encompasses the deinstitutionalization of certain practices, rules and norms and the reinstitutionalization of the new ones.

Institutional transitions are "fundamental and comprehensive changes introduced to the formal and informal rules of the game that affect organisations as players" (Peng 2003:275). The transition represents the period in which former institutions fade away, but still exist and in which the process of new institution formation starts but is not completed yet. Therefore, it is characterized by either the co-existence of two institutional frameworks or the absence of any.

When the two frameworks overlap or when there is no one institutional framework to guide organisational behaviour, there is a situation called institutional vacuum. The vacuum is characterized by chaos experienced by all actors in the economy. Hence studying the transition concept lies in studying the interaction between the 'old' institutional framework and the 'new' one (see Figure 2).

Figure 2: Institutional transition as a stage in the process of institutional change

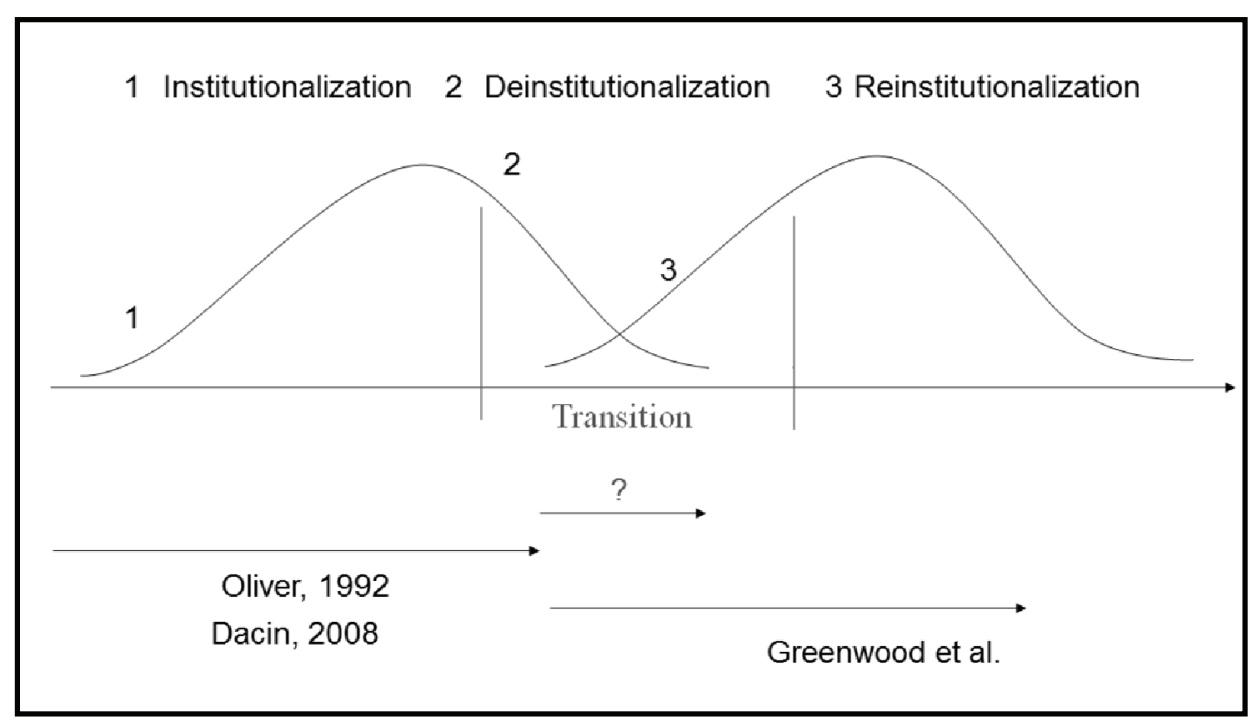


Generally, transition environments are settings which go through an institutional transition. Therefore, the institutional vacuum is inherent to all transition environments. All actors within the system experience elevated transaction costs (Meyer 2001) resulting from unclear regulatory frameworks and abundant opportunistic behaviour due to the lack of formal sanctions (TsuiAuch/Möllering 2010), unreliable market information, and underdeveloped institutions (i.e. the court systems) (Meyer 2001). The environmental instability produces ambiguity and uncertainty (Hitt et al. 2000). Therefore, transition environments greatly differ from those that are typical of Western contexts (McIntyre 2003; Peng/Heath 1996). Uncertainty surrounding exchange processes exist even in market-based economies; however, in transition contexts, the underdeveloped market-supporting institutions for regulating economic exchanges, weak laws and poor enforcement capacity of the formal legal institutions (Acquaah 2007) are additional sources of uncertainty which make the environment more complex and in which it is more difficult to operate. When studying transition, several situations may occur in terms of the predictability of change and the conflict between the co-existing institutional frameworks. If the transition is planned, for example through a change in the law, then organisations can prepare for the change (Stone and Brush 1996). However, most changes are not planned. While some 'old' rules of the game no longer work, the 'new' game has not been created yet. This leads to difficulties in predicting the future and in adopting adequate organisational behaviour. This condition is called organisational shortsightedness (or myopia), which results from the overall institutional upheaval (Peng/Heath 1996); the efforts to constantly adapt lead to an unstable environment.

Organisations in transition environments lose sight of the long-term merely because their survival in the short term requires their constant attention and effort.

Negative effects of transition environments, such as the organisational shortsightedness (myopia), the unreliable performance, the lack of trustworthiness, the low quality of products/services offered lead to the evaluations of firms being discounted by stakeholder groups. The discount that the evaluating audiences (both domestic and foreign) can apply to an organisation due to its context of origin is called liability of origin - a term coined by Bartlett and Ghoshal (2000). Liability of origin affects all organisations evolving in transition contexts, since it is based on the specificity of the environment itself. However, organisational size moderates the effect of the liability of origin because the smaller the organisation, the more vulnerable it is to the impact of the environment in which it operates.

The severity of the liability of origin depends on the phase of development of the transition environment; in particular whether it is at an early stage or a late one, as discussed below. 


\section{Phases in the development of the transition environment}

Based on the examination of transition economies, some authors (Peng 2003; Danis et al. 2010) conceptualize the transition process as comprising two stages - an early and a late phase. The early stage of the transition marks the process of deinstitutionalization of the rules, the norms and the values that are pertinent to the old institutional framework and the beginning of the creation of the new institutions (i.e. the reinstitutionalization of the new framework). In the late stage of the transition process, the new rules of the game become more firmly established as the institutions mature (Danis et al. 2010) while the old ones slowly fade away.

Generally, the liability of origin is more severe for organisations in the initial phase since the lack of legitimacy of the new ways to organise the economic activity is ubiquitous. As the institutions mature in the late phase of the transition process, the liability of origin experienced by the organisations operating in the transition environment starts to diminish. An explanation to the diminishing liability of origin is the increasing legitimacy of organisations. Liability of origin determines the need of an organisation to demonstrate its legitimacy or the adherence to the requirements and expectations of evaluating audiences. Based on the signalling theory of legitimacy (Ivanova/Castellano 2011), organisations can claim their legitimacy based on valid signals of legitimacy. A valid signal of legitimacy is an organisational characteristic, which is observable, costly to imitate (Spence 1973; 1974) and has a shared meaning between the claiming and granting entities (Ivanova/Castellano 2011). Since many theories are challenged when they are applied to transition environments (Peng et al. 2008), henceforth, we review organisational legitimacy to identify the specificities pertinent to the concept when it is applied to organisations operating in transition contexts.

\section{Legitimacy needs of organisations in transition environments}

Organisational legitimacy exists on the boundary between the organisation and its environment (Baum/Rowey 2003:6). In less vulnerable environments (i.e. developed economies), the environment-organisation relationship is more stable and as a result, it is clearer to identify the requirements of the legitimacygranting entities.

Hence, in stable environments, organisational legitimacy is perceived to be dichotomous - an organisation will be either legitimate when it meets the requirements or not if it deviates from them. In vulnerable contexts (such as transition environments), the relationship between the organisation and its environments, reflected in organisational legitimacy, is influenced by the instability of the environment. As a result, the change rate is elevated, and the rules, norms and beliefs are likely to change even over short periods of time. In such contexts, organisational legitimacy can be regarded as a continuous 
variable - organisations can accumulate legitimacy characteristics or legitimacy signals that eventually place them on a continuum ranging from least legitimate to most legitimate. At any given point in time, organisations can be compared based on their legitimacy stock.

The process of building the legitimacy stock is difficult due to the following two reasons: First, the meaning of signals in transition environments is not clearly defined or has not been established yet. For example, signals that are imported (e.g. ISO management standards) are not completely understood neither by the organisations that decided to adopt them nor by the audiences that evaluate them. It takes time for a shared meaning to be established. Second, in transition environments, there are many signals (e.g. quality awards) that are not interpreted in the same way. Such signals are not granted on merit but rather by corrupt practices. The organisations themselves get confused about how to establish their organisational legitimacy. Often, they act to sporadic opportunities and on the basis of scarce information.

As a result, the liability of origin determines the need for organisations to demonstrate their legitimacy. The question then is: what are the legitimacy needs of small organisations (vs. large ones) operating in transition environments? In the section below, we explore the legitimacy challenges of SMEs evolving in transitional contexts.

\section{Legitimacy needs of SMEs organisations in transition environments}

Today, small organisations are the most common type of enterprises (Soriano/Dobon 2009). Herein, we adopt the standard European Union definition according to which SMEs are organisations with fewer than 250 employees. This definition includes micro- (from 1 to 9 employees), small(from 10 to 49 employees) and medium- (from 50 to 249 employees) enterprises (McIntyre 2003:10).

We focused on the legitimacy needs of SMEs operating in transition environments. There are several reasons why the legitimacy needs of small and large organisations differ. First, small organisations have lower visibility. Extending the communist legacy, large organisation traditionally have been perceived as being more visible and legitimate (Shinkle/Kriauciunas 2010). Second, they face different institutional pressures in comparison to large organisations, most of which are privatized enterprises that were formerly stateowned (SOEs) (Peng 2003). In the early phase of the transition, the former SOEs can more easily extract protection and resources from the government and leverage their embedded relationships with regulative authorities (Peng 2003). In the late phase of the transition, former SOEs face greater legitimacy challenges since they are pressurized to improve their competitiveness and consequently their profitability as the government decreases its ownership (Zhu et al. 2007). 
Third, small organisations face a liability of smallness (Freeman et al. 1983). Usually, they have higher chances of failure (Freeman et al. 1983) since they have fewer resources, fewer well-trained managers, and fewer well-established relationships with creditors (Bruderl/Schussler 1990) and other external stakeholders (Singh, Tucker and House 1986). In transition environments, small organisations are even more vulnerable since they can more easily import instability from the environment (Smallbone et al. 1999).

Hereafter, we look at the SMEs' attempts in the late phase of the transition process to overcome the liability of origin and to gain organisational legitimacy.

\section{Signalling legitimacy}

In this study, we particularly investigated SMEs in transition environments vying for long-term outsourcing contracts. Signalling certain organisational characteristics helps the legitimacy-claiming entity bridge the information asymmetry that exists between the company itself and the legitimacy-granting audiences. Through signalling, the former communicates its compliance with the evaluating party's requirements and expectations. Normally, the outsourcers (e.g. clients) consider two main aspects of the organisation they evaluate in outsourcing arrangements (Quélin/Duhamel 2003), that is to say: first, whether the latter has the needed resources and competencies (which is captured by the concept of functional legitimacy), and, second, whether it is a trustworthy player (that is captured by the concept of relational legitimacy).

By operating in the markets for outsourcing services, the recipients of outsourcing contracts (which we will call herein "outsources") can rely on signals of functional and relational legitimacy in order to communicate their compliance with the requirements and expectations of the evaluating audiences. The conformity to stakeholder's expectations is a condition signifying organisational legitimacy.

Hence, it is hypothesized:

H 1: The higher the functional legitimacy of an organisation, the higher its organisational legitimacy.

H 2: The higher the relational legitimacy of an organisation, the higher its organisational legitimacy.

Moreover, we extend the analysis and test the relationship legitimacy-profitmaking-ability of an organisation.

\section{Profit-making ability of an organisation}

Organisational legitimacy is a valuable resource used to gain access to additional resources that organisations need for their activities (Pfeffer/Salancik 1978). Hence, legitimacy contributes significantly to the survival of organisations (Pfeffer/Salancik 1978). Some authors claim that an organisation 
can improve its profit-making ability by enhancing its legitimacy (Mazza 1999:42). Therefore, the ultimate sign of a legitimate organisation is its profit making ability (Mazza 1999:42). Hence, we hypothesize:

$H$ 3: The higher the organisational legitimacy, the higher its profitmaking ability.

In the next section, we analyse the concepts of functional and relational legitimacy by trying to identify their components.

\section{Functional and relational legitimacy}

Functional and relational legitimacy represent the two facets of this concept from a signalling perspective.

\section{Functional legitimacy}

Functional legitimacy signals the worthiness of a partner based on its access and/or control of important and valuable task-related resources and capabilities. When evaluating the task-related competencies of small technology-based organisations evolving in transition environments, several distinctive competencies were identified.

For instance, informational, managerial, organisational, innovative and symbolic reputational competencies (Leaonard-Barton 1992) represent different facets which build the construct of functional legitimacy.

The information competencies are related to the ability of an organisation to ensure access to relevant industry information. The evaluating audiences may consider the ability to ensure access to up-to-date industry information as an important organisational feature, especially in fast-paced industries/sectors.

In transition environments, managerial weaknesses (e.g. deficiencies in managerial and decision-making capabilities) are recognized as one of the most important factors that can inhibit the firm's ability to grow (Child/Pleister 2003). If the founding team members had Western or Western-like education and/or work experience, this leads to transfer of some knowledge and skills from the institution where the education and/or experience was acquired to the newlycreated venture. The Western education and/or work experience influences the way the managers communicate and negotiate as well as their commitment to the success of the arrangement.

The certificates granted by prestigious affiliates are the external recognition of certain organisational competencies. The association with prestigious affiliates decreases the uncertainty associated with the future prospects of the firm and consequently affects the stakeholders' evaluation of the company in a positive way (Titman/Trueman 1986; Carter/Manaster 1990; Gulati/Higgins 2003; Stuart 
et al. 1999). In order to be granted certificates by prestigious industry groups, organisations have to demonstrate their possession of certain competencies.

Organisational innovativeness is the "firm's commitment to the development and marketing of products that are new to the firm and/or the market" (Li/Atuahene-Gima 2001). Due to the instability of the context, there is a lack of managerial and financial resources to spend on the development of new product technologies (Hitt et al. 2000, Li/Atuahene-Gima 2001). As a result, new product development demonstrates not only sufficient resources but also that small organizations had developed the competencies to re-organize or re-group them in order to create new knowledge (Li/Atuahene-Gima 2001).

The symbolic reputational competencies are external representations of certain organisational competencies. Quality awards can be a valid signal of the superior competencies of small organisations operating in a transition environment since they are costly (in terms of effort) and observable (based on media coverage). They are particularly important in uncertain environments where judgments on quality should be made (Wade et al. 2006).

After the dimensions of the functional legitimacy were presented, in the next section, we review the dimensions of the other type of legitimacy, that is to say relational legitimacy.

\section{Relational legitimacy}

Relational legitimacy is associated with the reliability of an organization as a partner and the likelihood that it will with the specifications of a contract. In transition environments, small organisations trying to receive long-term contracts have to signal not only their ability to perform a task (which relates to functional legitimacy as explained previously) but also their ability to perform it while respecting the initially set deadlines and quality specifications (e. g. relational legitimacy).

Relational legitimacy includes valid signals of the organisational trustworthiness, accountability, stability and visibility (Ivanova/Castellano 2011). Below, the content of each dimension of the relational legitimacy is examined.

A company is trustworthy when it is known for not exploiting the vulnerabilities of other parties (Barney/Hansen 1994). Relationships between trustworthy partners are more stable to external pressures and show greater adaptability (Mohr/Spekman 1994). Signalling trustworthiness has an even higher significance for small organisations in transition environments due to their shortsightedness and the fact that they are often prone to behave opportunistically. Usually, the assessment is based on the past performance of the organisation under scrutiny. 
Organisational accountability is the ability of an organisation to account rationally for its actions (Hannan/Freeman 1984). They must be able to document how resources have been used and to reconstruct the sequences of organisational decisions, rules, and actions that produced particular outcomes (Hannan/Freeman 1984).

Organisational stability is based on routines which are "a repetitive, recognizable pattern of interdependent actions involving multiple actors" (Feldman/Pentland 2003). Routines are associated with reliable performance (Hannan/Freeman 1977; Meyer/Rowan 1977). The routines are an important aspect of the day-to-day operations of SMEs in transition environments because they allow the organisation to successfully manage the environmental volatility and reproduce the expected output.

Organisational visibility "is based upon characteristics that are likely to result in the organisation having a publicly recognized name" (Fuller et al. 2006). It is "an important attribute of organisations" (Brammer/Millington 2006) and a symbol of organisational success (Fuller et al. 2006).

After discussing the two independent constructs of functional and relational legitimacy, in the section below, we present the empirical setting in which the theoretical model proposed was tested.

\section{Empirical setting}

\section{The Bulgarian IT sector}

The theoretical framework presented was tested on the Bulgarian information technology (IT) sector. The IT sector in Bulgaria is highly-fragmented, comprised of more than 4,000 companies. ${ }^{2}$ Most of these companies are SMEs that is to say firms that employ up to 100 employees (Boychev and Monev 2007).

Forty-two percent of the Bulgarian IT employees are involved in software development and distribution, and 70 percent of their annual production is exported, almost exclusively through outsourcing contracts (Terzieff 2006).

The Bulgarian IT companies specialize in several technology niches (see Table 1).

2 Bulgarian ICT profile @ CEBIT 2006. 
Table 1: Specialization of the Bulgarian IT Companies (based on 500 companies included in Who is Who on the Bulgarian Computer Market?) August 4, 2008 .

\begin{tabular}{|l|c|}
\hline Type of specialization & Number of companies \\
\hline System integration & 102 \\
\hline Testing application software & 37 \\
\hline Service and support of computer equipment & 135 \\
\hline CAD/CAM/CAE systems & 18 \\
\hline Custom software & 81 \\
\hline Games & 13 \\
\hline Fonts \& cyrilization & 40 \\
\hline GIS & 25 \\
\hline Graphic software & 32 \\
\hline Management analysis IS & 33 \\
\hline $\begin{array}{l}\text { IS for manufacture management and } \\
\text { planning }\end{array}$ & 35 \\
\hline Databases & 87 \\
\hline Operation systems & 81 \\
\hline Test processing, text editors & 59 \\
\hline
\end{tabular}

The Bulgarian IT market has shown a steady growth over the years; an average annual growth rate of $15 \%$ was realized up to 2011 with IT services showing the greatest growth potential with an average annual growth rate of $70 \%$ and the hardware sector representing 17\% (ICT Media 2008).

The advantages of Bulgaria as an outsourcing destination come from low-cost, highly educated work force, combined with solid infrastructure, economic and political stability, geographic proximity and fewer security concerns. Based on the structure of the growth rates and the most sought IT skills, the organizations in Bulgaria are in the final stage of building their IT infrastructures (ICT Media 2008).

The high number of SMEs engaged in long-term contracts makes the Bulgarian IT sector an appropriate context to test the theoretical model presented in this study. We used the list of companies included in the IDG company catalogue (www.idg.bg). IDG is a Bulgarian IT portal for news, services and prices. Its news bulletin is highly valued among the Bulgarian IT experts. In the IDG Catalogue, the companies are divided in 4 categories, namely: Hardware, 
Software, Networks and Communication, and Services. Only the category Software was considered with its 526 company entries falling into 13 groups (see Table 2).

Table 2: IDG Catalogue - IT companies in the Software category

\begin{tabular}{|l|c|}
\hline IDG companies in category "Software" & $\#$ \\
\hline Distribution software & 78 \\
\hline Standard software development & 49 \\
\hline Customized software & 60 \\
\hline GIS applications \& distribution & 13 \\
\hline CAD/CAM/CAE & 23 \\
\hline Multimedia & 38 \\
\hline Data storage systems & 26 \\
\hline eBiz products/services & 53 \\
\hline ERP & 73 \\
\hline Documents processing & 31 \\
\hline Anti-virus software & 40 \\
\hline Information security & 34 \\
\hline GPS & 8 \\
\hline Total & $\mathbf{5 2 6}$ \\
\hline
\end{tabular}

It is important to note that the total number of companies was reduced to 461 since some companies can belong to several sub-groups in the Software Category. Moreover, an additional 150 companies were excluded due to various reasons, such as B2C business (11), foreign subsidiary (82), previously stateowned (3), large company (2), institutes/centers (9), online portals (1), contact information not found (14), main activity - not genuinely an IT firm (27), new company - less than one year old (1).

Hence, 311 firms were kept. We proceeded by contacting 225 of them by e-mail and 86 in person. Representatives of 95 companies agreed to fill out the questionnaire. This corresponds to a response rate of $31 \%$. After the consequent data examination and data cleaning, the final number of observations came to a total of 77 companies.

In order to test the proposed research model, structural equation modelling (SEM) technique was used. As the model shows the concepts of functional, relational and organisational legitimacy as well as the profit-making ability of an organisation are latent variables, they are not directly observable. The 
comprising elements of functional and relational legitimacy are manifest variables, since they can be directly observed. In addition, the latent construct of these two legitimacy types are formative - the causality goes from the observable variables to the manifest variable (Diamantopoulos/Winklhofer 2001).

The indicators and their corresponding measurements comprising the functional and relational legitimacy as well as the concept of organisational legitimacy and profit-making potential are presented in Table 3.

Table 3: Operationalisation of variables

\begin{tabular}{|c|c|c|l|}
\hline Variable & Measurement & Abbreviation & \multicolumn{1}{|c|}{ Operationalisation } \\
\hline $\begin{array}{c}\text { Informational } \\
\text { competency }\end{array}$ & $\begin{array}{c}\text { Association } \\
\text { membership }\end{array}$ & ASSOC & Number of association memberships \\
\hline $\begin{array}{c}\text { Innovative } \\
\text { competencies }\end{array}$ & $\begin{array}{c}\text { Own product } \\
\text { development }\end{array}$ & OWNPR & $\begin{array}{l}\text { OWNPR = 1(if the company has its } \\
\text { own product) and 0 (if the company } \\
\text { does not) }\end{array}$ \\
\hline $\begin{array}{c}\text { Managerial } \\
\text { competencies }\end{array}$ & $\begin{array}{c}\text { Managers } \\
\text { western } \\
\text { education }\end{array}$ & WEST & $\begin{array}{l}\text { WEST }=(\text { Number of founding team } \\
\text { members with Western or Western- } \\
\text { like education and/or } \\
\text { experience)/the total number of } \\
\text { founding team members)*100 }\end{array}$ \\
\hline $\begin{array}{c}\text { Organisational } \\
\text { competencies }\end{array}$ & $\begin{array}{c}\text { Prestigious } \\
\text { industry } \\
\text { affiliates }\end{array}$ & PART & $\begin{array}{l}\text { PART } \text { (\# of Registered* 0.1 +\# } \\
\text { of Silver*0.3 + \# of } \\
\text { Golden*0.6)*100 }\end{array}$ \\
\hline $\begin{array}{c}\text { Symbolic } \\
\text { reputational } \\
\text { competencies }\end{array}$ & Awards & AWARD & $\begin{array}{l}\text { AWARD = total number of quality } \\
\text { awards that an organisation has } \\
\text { received over the years }\end{array}$ \\
\hline
\end{tabular}

3 We adopted three level of partnerships - registered (the lowest), silver (middle) and golden (the high est). Different weights were allocated to the three levels since the higher the level of partnership, the more capabilities a company has to prove to possess. In example, being a Registered Microsoft Partner means that the company only distributes the products of Microsoft while being a Golden Microsoft Partner means that the company's employees went through a certification process and received Microsoft certificates for the possession of certain skills. In addition, the higher the level of partnership, the higher the technical support provided by the particular company that granted the certificate. Hence, the following weights were allocated -0.1 for registered, 0.3 for silver and 0.6 for golden partner. 


\begin{tabular}{|c|c|c|c|}
\hline \multicolumn{4}{|c|}{ Relational legitimacy } \\
\hline $\begin{array}{l}\text { Organisational } \\
\text { trustworthiness }\end{array}$ & $\begin{array}{l}\text { Clients' } \\
\text { reputation }\end{array}$ & CLREP & $\begin{array}{l}\operatorname{CLREP}^{4}=(0.1 * 1)+(0.2 * 1)+ \\
(0.3 * 2)+(0.4 * 1)=1.3\end{array}$ \\
\hline $\begin{array}{l}\text { Organisational } \\
\text { accountability }\end{array}$ & $\begin{array}{l}\text { Certified } \\
\text { standards }\end{array}$ & ISO & $\begin{array}{l}\text { ISO }=\text { number of years of } \\
\text { possession of the certificate }\end{array}$ \\
\hline $\begin{array}{l}\text { Organisational } \\
\text { stability }\end{array}$ & $\begin{array}{c}\text { Organisational } \\
\text { size }\end{array}$ & AGE & $\begin{array}{l}\text { AGE = number of years since the } \\
\text { initial legal incorporation of the } \\
\text { organisation }\end{array}$ \\
\hline $\begin{array}{l}\text { Organisational } \\
\text { visibility }\end{array}$ & $\begin{array}{l}\text { Physical } \\
\text { footprint }\end{array}$ & NOFFICE*LOC & $\begin{array}{l}\text { NOFFICE }^{*} \text { LOC }^{5}=\text { Total Number } \\
\text { of Offices } * \text { Location of HQ } \\
(\mathrm{SOF}=3, \mathrm{BIG}=2, \mathrm{SMALL}=1)\end{array}$ \\
\hline & $\begin{array}{c}\text { Virtual } \\
\text { footprint }\end{array}$ & WEBSITE & WEBSITE = 1(if yes) and 0 (if no) \\
\hline \multicolumn{4}{|c|}{ Organisational legitimacy } \\
\hline & $\begin{array}{l}\text { Number of } \\
\text { employees }\end{array}$ & EMPLS & $\begin{array}{l}\text { EMPLS = total number of } \\
\text { employees }\end{array}$ \\
\hline & $\begin{array}{l}\text { Number of } \\
\text { clients }\end{array}$ & NCLNTS & $\begin{array}{l}\text { NCLNTS = number of current } \\
\text { clients }\end{array}$ \\
\hline \multicolumn{4}{|c|}{ Profit-making potential } \\
\hline & $\begin{array}{l}\text { Average } \\
\text { fee/hour }\end{array}$ & AVFEE & $\begin{array}{l}\text { AVFEE = average fee/hour for } \\
\text { services rendered }\end{array}$ \\
\hline & Growth rate & GRWTH & $\begin{array}{l}\text { GRWTH = growth rate in sales } \\
\text { revenue (in \%) in } 2008 \text { compared to } \\
2007\end{array}$ \\
\hline
\end{tabular}

The SEM technique employed was PLS. The software package used is smartPLS 2.0 (M3) (Ringle et al. 2005). In order to get the indicator weights and path coefficients, we used the computational option given under the PLS algorithm (with maximum iterations of 300). In order to get the t-values, we

4 The client reputation of an organisation was measured as a function of the level of operation of its clients. Four levels of operation were identified - local (within the city), local with export activities (the market is locally-defined but the clients of the company have international activities), national and international. There is no clear cut between the three levels of operation and usually companies have clients on at least two levels. Hence, we allocated different weights to the three above-mentioned layers of the environment - local $(0.1)$, local with export activities (0.2), national (0.3) and international, such as a foreign subsidiary (0.4). The weights were allocated assuming that the reputation of a company will go up if its clients move from local to international level. Then, the number of companies among the 5 big clients was multiplied by the particular weight depending on the environmental level on which they function.

5 It is assumed that if the company's headquarters is located in the capital city of Sofia, its visibility will be higher in comparison to the other two options - big city (with more than 100,000 inhabitants) or small city (less than 100,000 inhabitants). The higher visibility is due not only to the size of the capital city (more than 2 million inhabitants) and the concentration of business activity there but also due the agglomeration effect based on the concentration of the IT companies themselves in Sofia. Thus, if a company's headquarters is based in Sofia, we coded it as $3(\mathrm{SOF}=3)$, in a big city as $2(\mathrm{BIG}=2)$, and in a small city as $1(\mathrm{SMALL}=1)$. Then, we multiplied the total number of offices to the weight allocated to each location. The higher the number received, the higher the number of potential constituencies the company is exposed to, thus the higher its organisational visibility. 
used the bootstrapping option (based on 1,000 samples) in smart PLS software package.

\section{Results}

The results after running the PLS algorithm are presented in Figure 3.

Figure 3: PLS Algorithm Output

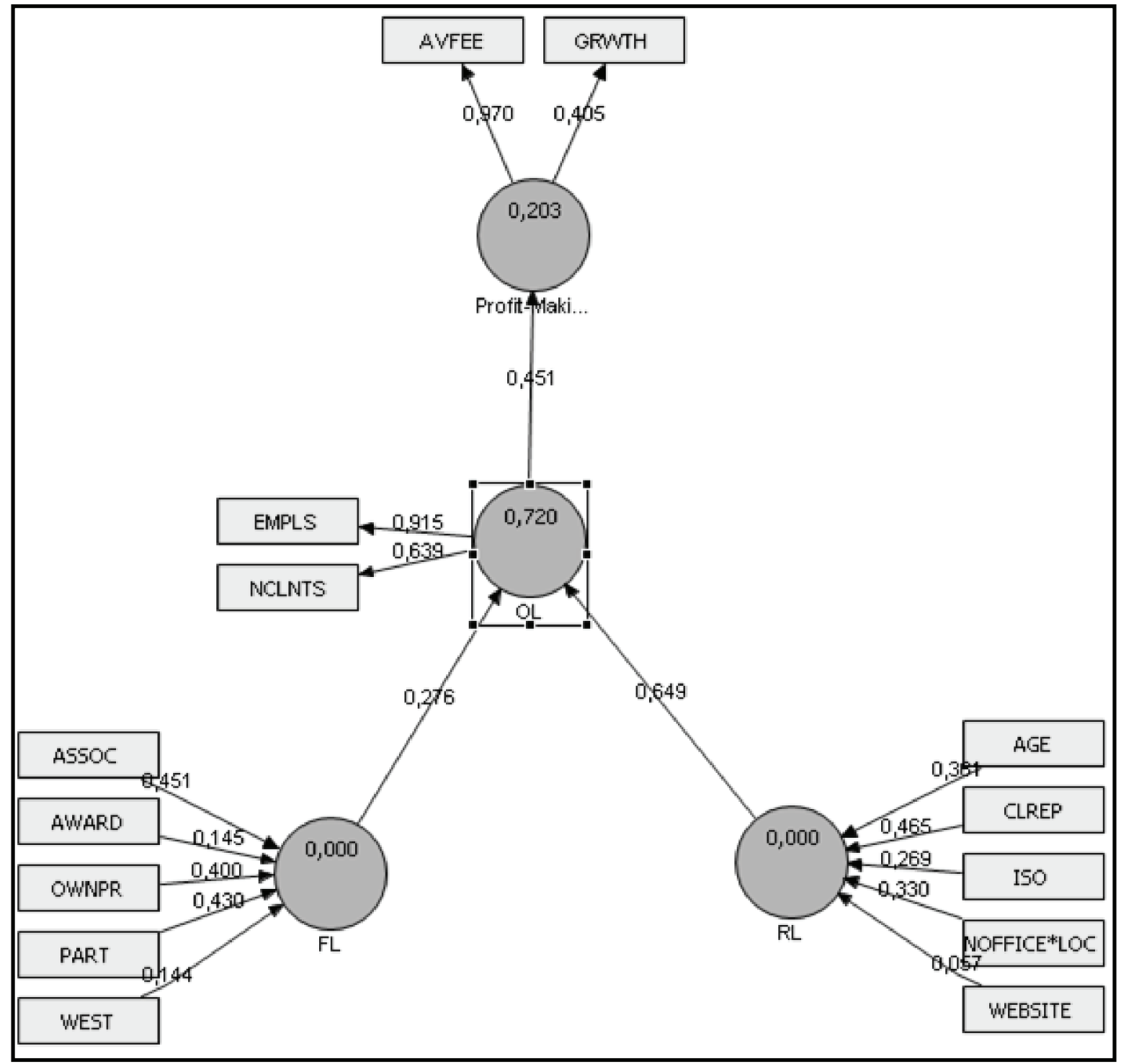

After running the bootstrapping calculation option of smartPLS, we were able to obtain the t-values of the indicator (outer) weights presented in Table 4. The results of the data analysis are presented in the table below. The indicators whose weights are significant at $p=0.10$ are highlighted. 
Table 4: PLS output on outer weights and path coefficients

\begin{tabular}{|c|c|c|c|c|c|}
\hline Indicator & Description & Variable & Weight & t-value & $\begin{array}{c}\text { p- } \\
\text { value }\end{array}$ \\
\hline \multicolumn{6}{|l|}{ Functional legitimacy } \\
\hline $\mathrm{X} 1$ & $\begin{array}{c}\text { Association } \\
\text { membership }\end{array}$ & ASSOC & 0.4510 & 2.8704 & 0,0042 \\
\hline $\mathrm{X} 2$ & $\begin{array}{c}\text { Organisation } \\
\text { innovativeness }\end{array}$ & OWNPR & 0.4000 & 3.7231 & 0,0002 \\
\hline $\mathrm{X} 3$ & $\begin{array}{c}\text { Manager's western } \\
\text { education }\end{array}$ & WEST & 0.1440 & 1.2584 & 0.2085 \\
\hline $\mathrm{X} 4$ & $\begin{array}{c}\text { Prestigious } \\
\text { industry affiliates }\end{array}$ & PART & 0.4300 & 2.5518 & 0.0109 \\
\hline $\mathrm{X} 5$ & Awards & AWARD & 0.1450 & 0.9782 & 0.3282 \\
\hline \multicolumn{6}{|l|}{ Relational legitimacy } \\
\hline $\mathrm{X} 6$ & $\begin{array}{c}\text { Certified } \\
\text { standards }\end{array}$ & ISO & 0.2690 & 3.0839 & 0.0021 \\
\hline $\mathrm{X} 7$ & Age & AGE & 0.3610 & 4.3870 & 0.0000 \\
\hline $\mathrm{X} 8$ & Client reputation & CLREP & 0.4650 & 5.9374 & 0.0000 \\
\hline X9 & Physical footprint & NOFFICE*LOC & 0.3300 & 4.8010 & 0.0000 \\
\hline $\mathrm{X} 10$ & Virtual footprint & WEBSITE & 0.0570 & 0.8676 & 0.3858 \\
\hline \multicolumn{6}{|l|}{$\begin{array}{c}\text { Organisational } \\
\text { legitimacy }\end{array}$} \\
\hline $\mathrm{X} 11$ & $\begin{array}{l}\text { Number of } \\
\text { employees }\end{array}$ & EMPLS & 0.9150 & 36.2905 & 0.0000 \\
\hline $\mathrm{X} 12$ & Number of clients & NCLNTS & 0.6390 & 5.7908 & 0.0000 \\
\hline \multicolumn{6}{|l|}{$\begin{array}{c}\text { Profit-making } \\
\text { potential }\end{array}$} \\
\hline $\mathrm{X} 13$ & Average fee/hour & AVFEE & 0.9700 & 26.8932 & 0.0000 \\
\hline $\mathrm{X} 14$ & Growth rate & GRWTH & 0.4050 & 2.0763 & 0.0381 \\
\hline \multirow[t]{4}{*}{ Path coefficients } & Description & Variable & Weight & t-value & $\begin{array}{c}\text { p- } \\
\text { value }\end{array}$ \\
\hline & FL - OL & FL & 0.2760 & 3.4178 & 0.0007 \\
\hline & $\mathbf{R L}-\mathbf{O L}$ & $\mathrm{RL}$ & 0.6490 & 8.0293 & 0.0000 \\
\hline & $\begin{array}{l}\text { OL - profit- } \\
\text { making }\end{array}$ & OL & 0.4510 & 6.1704 & 0.0000 \\
\hline
\end{tabular}

The assessment of the measurement and structural models are presented in detail in the following section.

\section{Assessing the measurement models}

\section{Functional legitimacy formative latent construct}

All indicators of the functional legitimacy formative construct besides product/service awards (AWARD) and Western education/experience of founding team members (WEST) are positive and significant at $\mathrm{p}=0.05$ (see Table 4). 
The indicator product/service awards AWARD has $\mathrm{t}=0.9782$ and corresponding $\mathrm{p}=0.3282(>0.10)$. The number of product/service awards enhances the functional legitimacy of an organisation (due to the positive sign of the indicator) but the effect is not statistically significant. The indicator Western and/or Western-like education/experience of the founding team members (WEST) has $\mathrm{t}=1.2584$ and a corresponding $\mathrm{p}=0.2085(>0.10)$. Western education/experience of the founding team members positively affects the functional legitimacy of an organisation, but the effect is not statistically significant.

\section{Relational legitimacy formative latent construct}

Four indicators (ISO, AGE, CLREP and NOFFICE*LOC) comprising the relational legitimacy formative construct are statistically significant at $\mathrm{p}=0.05$ (see Table 4).

The indicator showing whether a company has a website or not (WEBSITE) has $\mathrm{t}=0.8676$ and corresponding $\mathrm{p}=0.3858(>0.10)$. The indicator WEBSITE indeed measures a sub-dimension of the manifest variable organisational visibility, for which there is another measure NOFFICE*LOC. WEBSITE measures the virtual footprint dimension of organisational visibility while NOFFICE*LOC measures the physical footprint.

\section{Organisational legitimacy reflective latent construct}

In the reflective measurement model of organisational legitimacy, the indicators number of clients (NCLNTS) and number of employees (EMPLS) are positive and statistically significant at $\mathrm{p}=0.5$.

\section{Profit-making ability reflective latent construct}

In the reflective measurement model of profit-making potential, the indicators average fee/hour (AVFEE) and growth rate of sales revenue (GRWTH) are positive and statistically significant at $\mathrm{p}=0.05$.

There is little guidance in the literature on how to handle indicators which are not statistically significant (Diamantopoulos/Winklhofer 2001). (Henseler et al. 2009:302) state that "formative indicators should never be discarded simply on the basis of statistical outcomes." If insignificant indicators are excluded, the content of the latent construct may be altered (Jarvis et al. 2003). Hence, the researcher should keep both significant and insignificant formative indicators as long as they can find theoretical justification for this (Henseler et al. 2009). In addition, the PLS structural model estimates hardly change when the insignificant highly collinear indicators are excluded (Henseler et al. 2009). This specificity of PLS as a SEM technique provides additional support for the decision to keep the insignificant formative indicators in the measurement model (Henseler et al. 2009). 


\section{Assessing the structural model}

According to Henseler et al. (2009), the structural model can be evaluated based on the following criteria: the coefficient of determination $\left(\mathrm{R}^{2}\right)$, the individual path coefficients in terms of their sign, the magnitude and the significance, as well as the effect size $\left(f^{2}\right)$ which shows whether a predictor latent variable has a weak, medium or large effect on structural level.

In this case, the coefficient of determination $\mathrm{R}^{2}=0.720$ for organisational legitimacy, $72 \%$ in the variation of this latent variable can be explained by the signals of functional and relational legitimacy used by an organisation. According to Chin (1998), this level of $\mathrm{R}^{2}$ is substantive since it is higher than the threshold level of 0.67 .

In addition, the two path coefficients of the functional and relational legitimacy formative latent constructs are positive and significant at $p=0.05$. The path coefficient of the functional legitimacy construct has an inner weight of $0.276 \mathrm{t}$ $=3.4178, \mathrm{p}=0.0007)$. The path coefficient of the relational legitimacy construct has an inner weight of $0.649(\mathrm{t}=8.0293, \mathrm{t}=0.0000)$. Hence, hypotheses H1 and $\mathrm{H} 2$ are supported at $\mathrm{p}=0.05$. Signalling functional and relational legitimacy enhances the organisational legitimacy of small organisations in transition environments.

The effect size $\left(\mathrm{f}^{2}\right)$ of each of the independent variables (functional and relational legitimacy) on the dependent variable organisational legitimacy can be calculated (Cohen 1988). The effect size of the independent latent construct functional legitimacy is $\mathrm{f}^{2}=0.23$, while the effect size of the second independent latent construct relational legitimacy is much larger $\mathrm{f}^{2}=0.72$. Hence, the signals of relational legitimacy have much larger impact on the stakeholders' decision to grant legitimacy to a particular organisation.

We went a step further and tested the relationship organisational legitimacyprofit-making ability of an organisation. The coefficient of determination for the profit-making ability is $\mathrm{R}^{2}=0.203$. Even though this level of $\mathrm{R}^{2}$ is weak (Chin 1998), it shows that $20.3 \%$ of the variation in this latent variable can be explained by organisational legitimacy measured as the support by two important stakeholder groups, namely: employees and clients.

\section{Discussion}

The results of the statistical analysis show that the functional legitimacy of a small organisation in transition environment mainly depends on the company's innovativeness, its access to industry information, as well as the prestigious certified partnerships granted by global industry leaders. In highly dynamic sectors, being able to innovate sends an important signal that the company will exert an effort in potential partnerships. Having an access to the newest information is appreciated by the evaluating audiences since it ensures the 
adequate actions of the organisation under scrutiny. The effect is augmented for organisations evolving in transition environments characterized by a very high rate of change and instability. The legitimacy imported from the established global players based on certified partnerships is also highly appreciated by the stakeholders. The latter perceive the prestigious affiliates as being able to make better decisions on who to associate with.

The relational legitimacy of small organisations in transition environment is mainly based on client reputation, the physical footprint of the company and its age. Client reputation emphasizes the trustworthiness of an organisation as a partner and, hence, it is highly valued by the legitimacy-granting constituencies. Physical footprint represents the access points between the relevant stakeholders and the organisation, and it is an attribute on which high relative importance is placed. Being able to contact an entity increases the perception of reliability of the focal organisation. Additionally, organisational age, which conveys stability, is also highly valued. Moreover, the evaluating audiences appreciate organisations that are accountable for their internal processes, the external representation of which can be different management standards (ISO, CMMI, etc.).

Overall, signalling functional and relational legitimacy is important for SMEs in transition environments in order to get the support of the evaluating audiences. Furthermore, the relational legitimacy signals have more impact on the stakeholders' decision to support a particular organisation than the signals of functional legitimacy. Due to the overall instability in the environment and the excessive opportunistic behaviour exercised by the actors, demonstrating that a company is "there to stay" is crucial for its long-term success and survival.

The results of the study also show that the higher the legitimacy stock of an organisation, the higher its profit-making ability. Therefore, legitimacy is important to be pursued by small firms in transition environments since this can help them assure higher stakeholder support and eventually higher profit-making potential.

\section{Conclusion, limitations and avenues for future research}

The research contributes to the literature on transition environments, including transition economies, specifically relating to the second stage of the transition process (Peng 2003). Bulgaria started the process of transition from a planned to an open-market economy in 1989. Therefore, currently the country can be positioned at the second stage of the transition process. The IT sector is one of the most dynamic sectors in Bulgaria; it is highly fragmented and populated by numerous SMEs. Collecting data from the Bulgarian IT companies was the starting point to the understanding of some of the challenges that small businesses face in the second phase of the transition process. 
There is very little research on the challenges faced by SMEs in emerging (including transition) environments (Peng et al. 2008). Typically, transition economies rely on the growth of SMEs in order to spur economic prosperity (Peng 2000b). Even though SMEs are very important for the economic development of a nation, little is known on what distinguishes successful small ventures from the unsuccessful ones, especially in the transition context (Danis et al. 2010). This research provides insight into what makes some small organisations more successful than others in the context of institutional upheaval (Newman 2000) by examining the signalling of resources (functional) vs. relational competencies (relational legitimacy).

The practical implications for managers of SMEs in transition environments lies in building awareness of which signals are valued by various stakeholder groups, especially their clients (one of the main evaluating audiences in transition environments), and how to acquire and demonstrate such signals in order to be granted legitimacy.

For example, during the data collection, interviewees expressed their concern regarding the measurement of relational legitimacy. They all agreed though that it is very important to be signaled to relevant stakeholder groups. From the study, signals of relational legitimacy demonstrated better relative weight than signals of functional legitimacy. Hence, demonstrating reliability as a partner is more important in transition context than demonstrating organizational resources (which was also found to be statistically significant). A potential explanation of this is the proliferation of the opportunistic behavior by economic actors in transition environments. Therefore, small business managers in transition contexts have to recognize the importance of demonstrating their relational legitimacy - e. g. by using favorable previous client references.

In addition, managers of SMEs in transition environments tend to undermine certain signals, such as: association memberships. Based on the results, this signal was highly valued by the evaluating audiences showing that having an access to the newest information within a particular sector is important for interested stakeholders.

The study also has implications for public policy. Since many SMEs in transition environments are backward and occupy protected niches (Dallago and McIntyre, 2003), public policy (such as government agencies or cluster associations) can encourage them to identify and to adopt valuable signals in order to gain access to global markets. For example, the Capability Maturity Model Integration (CMMI) - a specific process standard in the IT industry - is promoted by the European Software Institute, which has branch offices in many European countries. One of the main purposes of this institute is to disseminate information and to assist small IT firms to adopt CMMI process standard. 
The limitations of this research relate to the type of data used, that is to say cross-sectional data. Even though the research design is based on a structured questionnaire as a data-collection instrument (Stevens et al. 2006), it does not provide longitudinal examination of the phenomenon under scrutiny. In addition, this research does not regard the specificities of the evaluating audiences on each layer of the environment (local, national, and international). Some results based on the exploratory study show interesting findings for organizations operating on the different layers of the environment. Some signals are not meaningful on certain environmental layers, such as maintaining a website on the local layer of the environment.

Hence, future studies could control for the layer of the environment on which the organizations operate (e.g. local, national and international/global), and examine the differences between the requirements and the expectations of the evaluating audiences at the different layers of the environment. Also, they could investigate the importance that the various stakeholder groups place on different signals at each layer. This may be important for managers operating on one layer, but also for the managers trying to shift from one layer to another, such as moving from national to international layer.

Also, future studies could test the proposed theoretical framework in different contexts. For example, researchers could compare organizations operating in transition environments to those operating in developed economies, or organizations that evolve in different type of transition environments, such as: Eastern Europe vs. China. Although transition economies exhibit similar economic and institutional characteristics, namely the social norms, culture, level of business and political risks, there are many differences among them (Acquaah 2007). Hence, a comparative study may yield interesting results which could enhance our understanding of the model proposed and the different transitional contexts.

\section{References}

Acquaah, M. (2007): Managerial Social Capital, Strategic Orientation, and Organisational Performance in an Emerging Economy, in: Strategic Management Journal, 28, 12351255.

Ashforth, B. E./Gibbs, B. W. (1990): The Double-Edge of Organisational Legitimation, in: Organisation Science, 1, 2, 177-194.

Barney, J. B./Hansen, Mark H. (1994): Trustworthiness as a Source of Competitive Advantage, in: Strategic Management Journal, 15, Special Issue, 175-190.

Bartlett, C. A./Ghoshal, S. (2000): Going Global: Lessons from Late Movers, in: Harvard Business Review, 78, 2, 132-142.

Baum, J. A. C./Oliver, C. (1991): Institutional Linkages and Organisational Mortality, in: Administrative Science Quarterly, 36, 2, 187-218. 
Berger, P. L./Luckmann, T. (1967): The Social Construction of Reality. New York: Anchor Books.

Bowen, F. E. (2000): Environmental Visibility: A Trigger of Green Organisational Response?, in: Business Strategy and the Environment, 9, 2, 92-107.

Boychev, A./Monev, D. (2007): Technology of the techno-deals: Why the Owners of Bulgarian IT Companies Started Selling Them to Stronger Foreign Players, in: Capital, 27, 6 July (http://www.capital.bg/show.php?storyid=356674\& $\mathrm{sp}=2$ \#storystart).

Brammer, S./Millington, A. (2006): Firm Size, Organisational Visibility and Corporate Philantropy: An Empirical Analysis, in: Business Ethics, 15, 1, 6-18.

Bruderl, J./Schussler, R. (1990): Organisational Mortality: The Liabilities of Newness and Adolescence, in: Administrative Science Quarterly, 35, 3, 530-547.

Bulgarian ICT Profile@ CEBIT 2006 (booklet)

Carter, R./Manaster, S. (1990): Initial Public Offerings and Underwriter Reputation, in: Journal of Finance, 45, 4, 1045-1067.

Child, J./Pleister, H. (2003): Governance and Management in China's Private Sector, in: Management International, 7, 3, 13-23.

Chin W. W. (1998): The Partial Least Squares to Structural Equation Modelling, Modern Methods for Business Research, in: Marcoulides, G.A. (ed.): Modern methods for business research, Mahwah: Lawrence Erlbaum Associates, 295-336.

Dallago, B./McIntyre, R. J. (2003): Conclusions: The Role of Public Policy in SME Development, in: McIntyre, R.J./Dallago, B. (ed.): Small and Medium Enterprises in Transitional Economies, Basingstoke, Hampshire: Palgrave Macmillan.

Danis, W. M./Chiaburu, D. S./Lyles, M. A. (2010): The Impact of Managerial Networking Intensity and Market-Based Strategies on Firm Growth during Institutional Upheaval: A Study of Small and Medium-Sized Enterprises in a Transition Economy, in: Journal of International Business Studies, 41, 287-307.

Diamantopolous, A./Winklhofer, H. M. (2001): Index Construction with Formative Indicators: An Alternative to Scale Development, in: Journal of Marketing Research, $38,2,269-277$.

Feldman, M. S./Pentland, B. T. (2003): Reconceptualising Organisational Routines as a Source of Flexibility and Change, in: Administrative Science Quarterly, 48, 1, 94-118.

Filatotchev, I./Hoskisson, R.E./Buck, T./Wright, M. (1996): Corporate Restructuring in Russian Privatizations: Implications for U.S. Investors, in: California Management Review, 38, 87-105.

Freeman, J./Carroll, G. R./Hannan, M. T. (1983): The Liability of Newness: Age Dependence in Organisational Death Rates, in: American Sociological Review, 48, 5, 692-710.

Fuller, B. J./Hester, K./Barnett, T./Frey, L./Relyea, C./Beu, D. (2006): Perceived External Prestige and Internal Respect: New Insights into the Organisational Identification Process, in: Human Relations, 59, 6, 815-846.

Hannan, M. T./Freeman, J. (1984): Structural Inertia and Organisational Change, in: American Sociological Review, 49, 2, 149-164. 
Henseler, J./Ringle, C. M./Sinkovics, R. R. (2009): The Use of Partial Least Squares Path Modeling in International Marketing, in: Advances in International Marketing, 20, 277-319.

Hitt, M. A./Dacin, T. M./Levitas, E./Arregle, J-L./Borza, A. (2000): Partner Selection in Emerging and Developed Market Contexts: Resource-Based and Organisational Learning Perspectives, in: Academy of Management Journal, 43, 3, 449-467.

Hitt, M. A./Ireland, D. R./Camp, M. S./Sexton, D. L. (2001): Strategic Entrepreneurship: Entrepreneurial Strategies for Wealth Creation, in: Strategic Management Journal, 22, 6-7, 479-491.

Hitt, M. A./Ahlstrom, D./Dacin, T. M./Levitas, E./Svobodina, L. (2004): The Institutional Effects on Strategic Alliance Partner Selection in Transition Economies: China vs. Russia, in: Organisation Science, 15, 2, 173-185.

ICT Media. (2008): 23.4\% Growth for the Bulgarian IT Market in 2007: Utilities, Healthcare and Manufacturing Expected to Become the Heaviest Investors in IT. http://en.ictmedia.bg/?mode=topics $\& \mathrm{t}=1 \& \mathrm{sbt}=1 \& \mathrm{id}=44$.

Ivanova, O./Castellano, S. (2011): The Impact of Globalization on Legitimacy Signals - The Case of SMEs in Transition Environments, in: Baltic Journal of Management, 6, 1, 105-123.

Jarvis, C. B./MacKenzie, S. B./Podsakoff, P. M. (2003): A Critical Review of Construct Indicators and Measurement Model Misspecification in Marketing and Consumer Research, in: Journal of Consumer Research, 30, 2, 199-218.

Gulati, R./Higgins, M. (2003): Which Ties Matter When? The Contingent Effects of Interorganisational Partnerships on IPO Success, in: Strategic Management Journal, $24,2,127-144$.

Leonard-Barton, D. (1992): Core Capabilities and Core Rigidities: A Paradox in Managing New Product Development, in: Strategic Management Journal, 13, Special Issue, 111125 .

Li, H./Atuahene-Gima, K. (2001): Product Innovation Strategies and the Performance of New Ventures in China, in: Academy of Management Journal, 44, 6, 1123-1134.

Mazza, C. (1999): Claim, Intent, and Persuasion: Organisational Legitimacy and the Rhetoric of Corporate Mission Statements. London: Kluwer Academic Publishers.

McIntyre, R.J. (2003): Small Enterprises in Transition Economies: Causal Puzzles and PolicyRelevant Research, in: McIntyre, R.J./Dallago, B. (eds.): Small and Medium Enterprises in Transitional Economies, New York: Palgrave Macmillan.

Meyer, K. E. (2001): Institutions, Transaction Costs, and Entry Mode Choice in Eastern Europe, in: Journal of International Business Studies, 32, 2, 357-367.

Meyer, J. W./Rowan, B. 1977. Institutionalized Organisations: Formal Structure as Myth and Ceremony, in: American Journal of Sociology, 83, 2, 340-363.

Meznar, M. B./Nigh, D. (1995): Buffer or Bridge? Environmental and Organisational Determinants of Public Affairs Activities in American Firms, in: Academy of Management Journal, 38, 4, 975-996. 
Mohr, J./Spekman, R. (1994): Characteristics of Partnership Success: Partnership Attributes, Communication Behaviour, and Conflict Resolution Techniques, in: Strategic Management Journal, 15, 2, 135-152.

Newman, K. L. (2000) Organisational Transformation during Institutional Upheaval, in: Academy of Management Review, 25, 3, 602-619.

Parsons, T. (1960): Structure and Process in Modern Societies. New York: The Free Press.

Peng, M. W. (2003): Institutional Transitions and Strategic Choices, in: Academy of Management Review, 29, 2, 275-296.

Peng, M. (2000a): Business Strategies in Transition Economies. Thousand Oaks: Sage Publications.

Peng, M. W. (2000b): Controlling the Foreign Agents: How Governments Deal with Multinationals in a Transition Economy, in: Management International Review, 40, 2, 141-165.

Peng, M. W./Heath, P. S. (1996): The Growth of the Firm in Planned Economies in Transition: Institutions, Organisations and Strategic Choice, in: Academy of Management Review, 21, 2, 492-528.

Peng, M. W./Wang, D.Y.L./Jiang, Y. (2008): An Institutional-Based View of International Business Strategy: A Focus on Emerging Economies, in: Journal of International Business Studies, 39, 920-936.

Peppard, J./Lambert, R./Edwards, C. (2000): Whose Job Is It Anyway? Organisational Information Competencies for Value Creation, in: Journal of Information Systems, 10, 291-322.

Pfeffer, J./Salancik, G. [1978] (2003): The External Control of Organisations: A Resource Dependence Perspective, $2^{\text {nd }}$ ed., Stanford: Stanford University Press.

Rao, H./Monin, P./Durand, R. (2003): Institutional Change in Toque Ville: Nouvelle Cuisine as an Identity Movement in French Gastronomy, in: American Journal of Sociology, $108,4,795-843$.

Ringle, C. M./Wende, S./Will, A. (2005): SmartPLS 2.0. (M3) Beta, Statistical Software, Hamburg: Germany.

Scott, R. W. (2001): Institutions and Organisations, $2^{\text {nd }}$ ed., Thousand Oaks: Sage Publications.

Shinkle, G. A./Kriauciunas, A. P. (2010): Institutions, Size and Age in Transition Economies: Implications for Export Growth, in: Journal of International Business Studies, 41, 267286.

Singh, J. V./Tucker, D. J./House, R. J. (1986): Organisational Legitimacy and the Liability of Newness, in: Administrative Science Quarterly, 31, 2, 171-193.

Smallbone, D./Piasecki, B./Venesaar, U./Todorov, K./Labrianidis, L. (1999): Internationalization and SME Development in Transition Economies: An International Comparison, in: Journal of Small Business and Enterprise Development, 5, 4, 363375 .

Soriano, D. R./Dobon, S. R. (2009): Linking Globalization of Entrepreneurship in Small Organisations, in: Small Business Economics, 32: 233-239. 
Spence, M. A. (1973): Job Market Signalling, in: Quarterly Journal of Economics, 87, 3, 355374.

Spence, M. A. (1974): Market Signalling: Informational Transfer in Hiring and Related Screening Processes. Cambridge: Harvard University Press.

Stefanova, D. (2008): The Business Still Does Not Trust the IT Outsourcing, in: Dnevnik, 19 June.

Stevens, R. E./Wrenn, B./Sherwood, P. K./Ruddick, M. E. (2006): The Marketing Research Guide. New York: The Haworth Press, Inc.

Stone, M. M./Brush, C. G. (1996): Planning in Ambiguous Contexts: The Dilemma of Meeting Needs for Commitment and Demand for Legitimacy, in: Strategic Management Journal, 17, 8, 633-652.

Stuart, T. E./Hoang, H./Hybels, R. C. (1999): Interorganisational Endorsements and the Performance of Entrepreneurial Ventures, in: Administrative Science Quarterly, 44, 2, 315-349.

Terzieff, J. (2006): For Outsourcing, Bulgaria is 'In': Proximity to Western Europe, U.S. Makes It an Attractive Option, in: Chronicle Foreign Service, May 16.

Titman, S./Trueman, B. (1986): Information Quality and the Valuation of New Issues, in: Journal of Accounting and Economics, 8, 159-172.

Tsui-Auch, L. S./Möllering, G. (2010): Wary Managers: Unfavorable Environments, Perceived Vulnerability, and the Development of Trust in Foreign Enterprises, in: Journal of International Business Studies, 41, 1016-1035.

Quélin, B./Duhamel, F. (2003): Bringing Together Strategic Outsourcing and Corporate Strategy: Outsourcing Motives and Risks, in: European Management Journal, 21, 5, 647-661.

Uzzi, B. (1997): Social Structure and Competition in Interfirm Networks: the Paradox of Embeddedness, in: Administrative Science Quarterly, 42, 1, 35-67.

Zhu, H./Hitt, M.A./Tihanyi. (2006): The Internationalization of SMEs in Emerging Economies: Institutional Embeddedness and Absorptive Capacities, in: Journal of Small Business Strategy, 17, 2, 1-26.

Zukin, S./DiMaggio, P. (1990): Structures of Capital: The Social Organisation of the Economy. Cambridge: Cambridge University Press. 